\title{
HMGA2/LPP Long Fusion Protein
}

National Cancer Institute

\section{Source}

National Cancer Institute. HMGA2/LPP Long Fusion Protein. NCI Thesaurus. Code C99422.

A fusion protein encoded by the HMGA2/LPP fusion gene. This protein is comprised of the AT-hook DNA binding domain of the high mobility group protein HMGI-C fused to the C-terminal proline-rich region and all three LIM domains of the lipoma-preferred partner protein. 